\title{
On the Antigenic Relationships of Certain Gitrobacter and Hafnia Cultures
}

\author{
BY J. SEDLÁK AND MARIE SLAJSOVÁ \\ Institute of Microbiology, Medical Faculty of Hygiene, Charles \\ University, Prague, Czechoslovakia
}

(Received 26 October 1965)

\section{SUMMARY}

The biochemical and serological characters of 36 unclassified cultures are described, and according to these characters the organisms belong to the genera Citrobacter, Aerobacter and Hafnia. While studying the antigenic relationships of the $\mathbf{O}$ antigens the known antigenic relationship between some serotypes of Citrobacter and Salmonella was confirmed; new antigenic relationships with $S$. locarno, $S$. kentucky, $S$. uccle and $S$. tranoroa are described. The antigenic relationships of the Hafnia cultures with Shigella flexneri $4 \mathrm{a}$ and with two cultures with a provisional $\mathrm{O}$ group of Citrobacter were confirmed.

\section{INTRODUCTION}

The antigenic relationship between the genus Citrobacter and the genera Salmonella, Arizona, Escherichia and Shigella have been relatively thoroughly described, mainly in the monographs of Kauffmann (1941, 1954, 1961), Edwards \& Ewing (1955, 1962), Sedlák \& Rische (1961), Kampelmacher (1959). Much less is known about the antigenic relationship between the other genera of this family, Enterobacteriaceae.

The present work aims to improve our knowledge about the antigenic relationships of some of the less common enteric bacteria. We believe that knowledge of these relationships and their further systemic study will lead to a decrease of false diagnoses made on biochemical grounds. The antigenic diagnostic schemes for the groups Salmonella (Kauffmann, 1964), Arizona (Edwards, West \& Brunner, 1948), Citrobacter (West \& Edwards, 1954), as well as Escherichia coli (Kauffmann, 1954) form the basis for a further systematic study of relationships that are important both practically and theoretically.

\section{METHODS}

Cultures studied. The biochemical and antigenic properties of 36 cultures of Citrobacter were studied. All these strains were isolated from human pathological material during the period 1936-65. Their designations and origin are presented in Table 1.

Strains Salmonella coli 1-5, together with $S$. ballerup $\left(\mathrm{Vi}, \mathrm{z}_{14}\right)$ and $S$. arizona (XXXIII : $z_{4} z_{23} z_{26}$ ) were originally listed by Kauffmann (1941) in the 1940 edition of the Kauffmann-White scheme and only later removed. $S$. arizona has become the test culture for serological group 01 of the present genus Arizona (Edwards, West \& 
Brunner, 1948) and $S$. ballerup one of the test cultures of the former 'Ballerup group' (Brunner, Edwards \& Hopson, 1949), and is at present the test culture for the serological group 029 of Citrobacter (West \& Edwards, 1954).

\begin{tabular}{|c|c|c|}
\hline $\begin{array}{l}\text { Origin. } \\
\text { designation } \\
\text { of cultures }\end{array}$ & $\begin{array}{l}\text { Originally described or } \\
\text { identified as }\end{array}$ & Received from \\
\hline $\begin{array}{l}\mathbf{2 6 2 4} / \mathbf{3 6} \\
\mathbf{5 3 9 6} / 38 \\
\mathbf{4 9 1} / \mathbf{3 6} \\
\mathbf{5 8 2 1} / \mathbf{3 8} \\
\text { 'Zurich' } \\
\text { 'Ka' } \\
\text { 'B' }\end{array}$ & 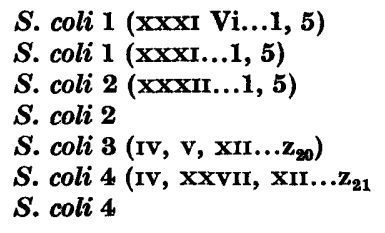 & $\begin{array}{l}\text { Prof. Dr F. Kauffmann, International } \\
\text { Salmonella Centre, Statens Serum } \\
\text { Institut, Copenhagen, Denmark }\end{array}$ \\
\hline $\begin{array}{l}\text { LG } 1099 \\
\text { Br } 184 / 6\end{array}$ & $\begin{array}{l}\text { Citrobacter (Sa O3, 10, 19) } \\
\text { Citrobacter (Sa O8, 20) }\end{array}$ & $\begin{array}{l}\text { Prof. Dr E. van Oye, National Salmonella- } \\
\text { Shigella Centre, Brussels, Belgium }\end{array}$ \\
\hline $\begin{array}{l}\text { Ci } 47007 \\
\text { Ci } 47009,47010 \\
\text { Ci } 47012,57015 \\
\text { Ci } 47018,47020\end{array}$ & Citrobacter & $\begin{array}{l}\text { Dr Lányi, State Institute of Hygiene, } \\
\text { Budapest, Hungary }\end{array}$ \\
\hline $\begin{array}{l}\text { н } 8997 \text {, н } 9004 \text {, } \\
\text { н } 9011 \text {, н } 9012, \\
\text { н } 9013, \text { н } 9009 \text {, } \\
\text { н } 9020 \text { н } 9022, \\
\text { в } 9024, \text { н } 9025 \text {, } \\
\text { н } 9008 \text {, н } 9027\end{array}$ & Hafnia & $\begin{array}{l}\text { Dr E. Aldová, National Shigella Centre, } \\
\text { Institute of Epidemiology and Micro- } \\
\text { biology, Prague, Czechoslovakia }\end{array}$ \\
\hline $\begin{array}{l}\text { P } 6 \text { b } \\
\text { P } 11 \text { c } \\
\text { P } 310 a \\
\text { w } 40\end{array}$ & $\begin{array}{l}\text { E. coli } 067 \\
\text { E. coli } 072 \\
E . \text { coli } 094 \\
\text { E. coli } 0122\end{array}$ & $\begin{array}{l}\text { Dr F. Orskow, International Escherichia } \\
\text { Centre, Statens Serum Institut, Copen- } \\
\text { hagen, Denmark }\end{array}$ \\
\hline
\end{tabular}

Cultures P 6b, 11c, н 310, w 40 are provisional test cultures of Escherichia coli serological groups 0 67, 0 72, 094 and 0122 (Kauffmann, 1954), but have been characterized by Kauffmann as '... atypical in that they are indole negative, $\mathrm{H}_{2} \mathrm{~S}$ positive (ferric chloride gelatin) and ammonium citrate positive, i.e. they belong to the Bethesda group (or to Escherichia freundii)' (Kauffmann, 1954, p. 178). The other cultures were isolated by us much later (1963-65) and have not been previously described. The antigenic relationship of strains LG 1099 and 184/6 with Salmonella anatum and $S$. kentucky was shown by E. van Oye.

For the biochemical identification of the cultures the methods and culture media recommended by the Enterobacteriaceae Subcommittee (Reports, 1958) or by Kauffmann (1941, 1954), Edwards \& Ewing (1955, 1962), or Kauffmann \& Petersen (1956) were used.

Serological examination was done by the methods of slide agglutination and agglutination in test-tubes. Antigenic relationships were studied by using crossagglutination and in some cases also absorption tests with the respective anti-O or anti-H sera of our own make.

After determination of the $O$ antigens of our Citrobacter strains and their allocation to one of the serological $O$ groups, we had at our disposal all the necessary 


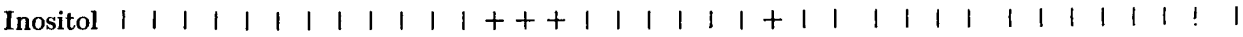

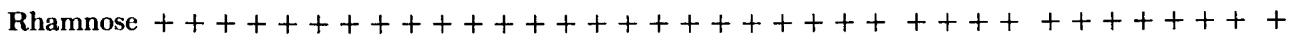
Sorbitol $t+t++1+t+t+t+t+t+t+t+t+t+\begin{array}{llllllllllllll}1 & 1 & 1 & 1 & 1 & 1 & 1 & 1 & 1 & 1 & 1 & 1\end{array}$

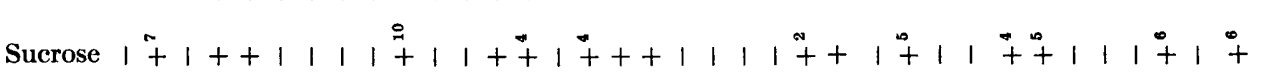

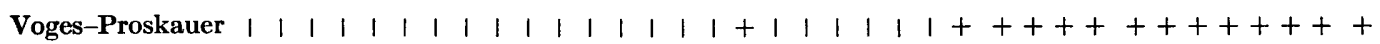

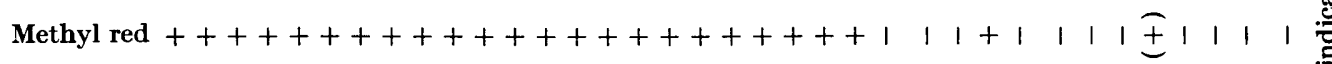
Sodium citrate $++++++++++++++++1+++++++++1++++++++2$ D-tartrate 1

Mucate $t+t+t+t+1 \quad 1 \quad 1+t+t+t+t+1 \quad 1+t+\begin{array}{llllllllllll}1 & 1 & 1 & 1 & 1 & 1 & 1 & 1 & 1 & 1 & 1 & 0\end{array}$ Salicin $11111+11111111+11111++1++++1+11+11++$

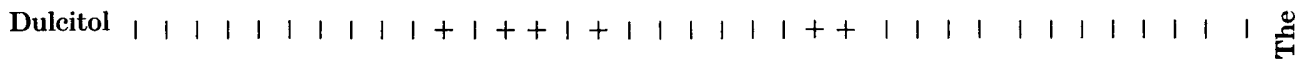

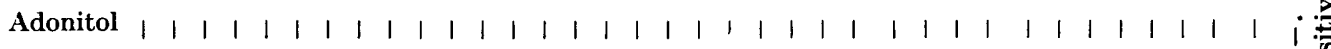

Lysine

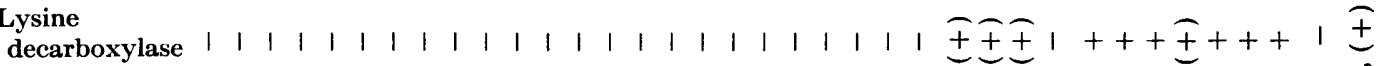

Ornithine

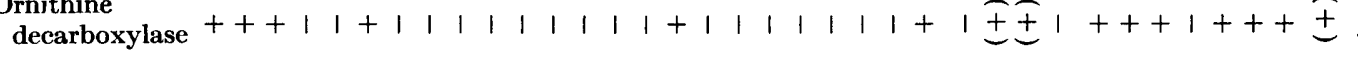

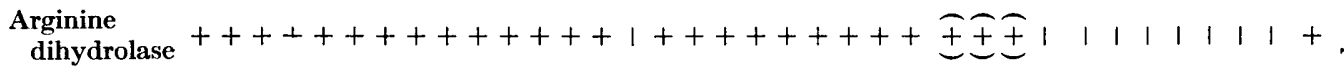
Malonate $111111++1+11111+11111111+++1|1| 1+11++$

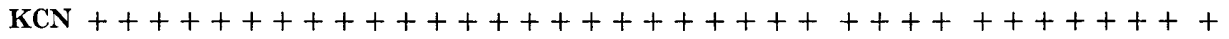

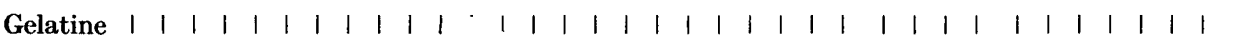

\section{Phenylalanine} deaminase

Citrate

$\underset{\text { (Simmons) }}{\text { Citrate }}++++++++++++++++++++++++11+++++++11$

Urease

(Christensen)

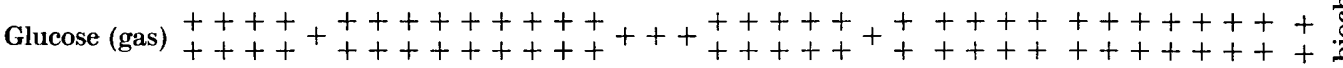

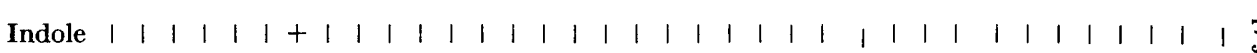

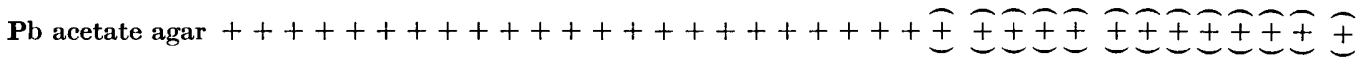
TSI Agar $++++++++++++++\begin{array}{llllllllllllllllllllllll} & + & 1 & 1 & 1 & 1 & 1 & 1 & 1 & 1 & 1 & 1 & 1 & 1 & 1 & 1 & 1 & 1 & 1 & 1 & 1 & 1 & 1\end{array}$

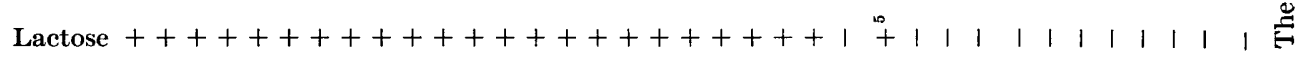

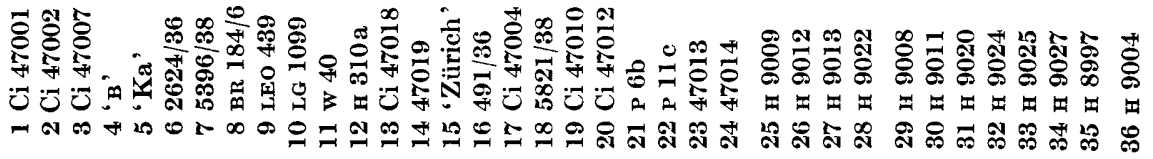


anti-O sera according to the original antigenic Citrobacter scheme of West \& Edwards (32 serological $O$ groups); in addition to these we had a further eight of our own anti-O sera (provisional new groups 0 33-0 40; Table 4).

\section{RESULTS}

All the cultures corresponded to the basic taxonomic definition of the family Enterobacteriaceae in Bergey's Manual (1957) and to the definition of one or other of two genera of this family, i.e. Citrobacter or Enterobacter.

Table 3. Antigenic relationships

\begin{tabular}{|c|c|c|c|c|}
\hline \multirow[b]{2}{*}{$\begin{array}{l}\text { Designation of } \\
\text { cultures }\end{array}$} & \multicolumn{4}{|c|}{ Serological $\mathrm{O}$ groups } \\
\hline & $\begin{array}{c}\text { Citrobacter } \\
\text { West \& Edwards } \\
\text { O 1-0 32 }\end{array}$ & $\begin{array}{c}\text { Salmonella } \\
\text { Kauffmann-White } \\
\text { A-0 60 }\end{array}$ & Shigella & $\begin{array}{c}\text { E. coli } \\
(\text { O } 1-0 \text { 144) }\end{array}$ \\
\hline Citrobacter & prov. 033-041 & & & \\
\hline $\left.\begin{array}{l}\mathbf{2 6 2 4 / 3 6} \\
\mathbf{5 3 9 6 / 3 8}\end{array}\right\}($ S. coli 1$)$ & 一 & $\begin{array}{l}\text { O } 48 \text { (ident.) } \\
\quad(S . \text { djakarta) }\end{array}$ & - & - \\
\hline $\left.\begin{array}{l}\text { 491/36 } \\
5821 / 38\end{array}\right\}($ S. coli 2$)$ & - & H 1,5 & - & - \\
\hline $\begin{array}{l}\text { 'Zürich', (S. coli 3) } \\
\text { 'в', 'кa' (S. coli 4) } \\
\text { Ci 47004 }\end{array}$ & O 22 & $\begin{array}{l}\text { O 4, } 5(S . \text { para- } \\
\text { typhi B) }\end{array}$ & - & - \\
\hline $\left.\begin{array}{l}\text { Ci } 47001 \\
\text { Ci } 47018 \\
\text { Ci } 47019\end{array}\right\}$ & 012 & O 57 (S. locarno) & - & - \\
\hline $\left.\begin{array}{l}\text { LEO } 429 \\
\text { w } 40\end{array}\right\}$ & Prov. O 36 (151) & - & - & O 122 \\
\hline $\operatorname{Br} 184 / 6$ & $\begin{array}{c}\text { Prov. O' } 38 \\
(138 \text { A) }\end{array}$ & $\begin{array}{l}\text { O 8, 20 } \\
\quad(\text { S. kentucky })\end{array}$ & 一 & 一 \\
\hline $\begin{array}{l}\text { LG } 1099 \\
\text { Ci } 47013\end{array}$ & Prov. O 37 (153) & $\begin{array}{l}\text { O 3, 10, } 19 \\
\quad(\text { S. anatum })\end{array}$ & S. flexneri $4 \mathrm{a}$ & 一 \\
\hline Ci 47012 & - & O 54 (S. uccle) & - & - \\
\hline Ci 47010 & - & O 55 (S. tranoroa $)$ & - & - \\
\hline Ci 47002 & - & VI & - & - \\
\hline $\mathbf{P}$ 6b & - & - & 一 & O 67 (ident.) \\
\hline P 11c & - & - & - & O 72 (ident.) \\
\hline II $310 a$ & - & - & - & O 94 (ident.) \\
\hline $\begin{array}{l}\text { Hafnia } \\
\left.\quad \begin{array}{l}\text { H } 8997 \\
\text { H } 9009\end{array}\right\}\end{array}$ & Prov. O 37 (153) & - & S. flexneri $4 \mathbf{a}$ & Ee ( O 1), O 13 \\
\hline $\left.\begin{array}{l}\text { н } 9008, \text { н } 9011 \\
\text { н 9004, н } 9020 \\
\text { н } 9025, \text { н } 9027 \\
\text { н } 9012, \text { н } 9013 \\
\text { н } 9024\end{array}\right\}$ & - & - & S. flexneri $\mathbf{4 a}$ & - \\
\hline
\end{tabular}

The biochemical characteristics of all the cultures are shown in Table 2 . It is obvious from this Table that 24, of the cultures can, by their biochemical properties, be identified as typical members of the genus Citrobacter. Small deviations from the existing definition of the genus Citrobacter (Edwards \& Ewing, 1962) were shown by 
the indole-positive variant 5396/38 Salmonella coli 1, and the anaerogenic variants 'Zürich' S. coli 3, 491/36 S. coli 2, 'Ka' S. coli 4, Ci 47004 and Ci 47013. Only five cultures fermented sodium malonate and five cultures salicin.

Production of hydrogen sulphide $\left(\mathrm{H}_{2} \mathrm{~S}\right)$ was detected in all cultures after $24 \mathrm{hr}$ incubation on lead acetate agar and in 14 cultures also on TSI agar.

All the other cultures belong to the genus Aerobacter (Bergey's Manual, 1957; Edwards \& Ewing, 1962). Twelve of them could be included in the Hafnia group (Møller, 1954; Edwards \& Ewing, 1962) and one of these (Ci 47014) corresponds to the definition of the species variously known as Aerobacter cloacae or Cloaca cloacae (Kauffmann, 1954), Enterobacter (Hormaeche \& Edwards, 1959) or Aerobacter group A (Edwards \& Ewing, 1962). In none of the cultures was $\mathrm{H}_{2} \mathrm{~S}$ production detected on TSI agar, not even after prolonged incubation. The production of small quantities of $\mathrm{H}_{2} \mathrm{~S}$ could be proved only on lead acetate agar after prolonged incubation at $22^{\circ}$. After incubation at $37^{\circ}$ the MR and VP tests did not give clear positive or negative results. The results of these tests reported in Table 2 were after incubation at $\mathbf{2 2}^{\circ}$.

Table 4. Antigenic properties of 10 new provisional O-type cultures

\begin{tabular}{|c|c|}
\hline $\begin{array}{l}\text { Original designation } \\
\text { of studied cultures }\end{array}$ & $\begin{array}{l}\text { O-type culture of provisiona } \\
\text { serological groups } \mathrm{O} 33-\mathrm{O} \\
\text { (relationship of } \mathrm{O} \text { antigen) }\end{array}$ \\
\hline $\mathbf{P} \mathbf{6 b}$ & O 33 (E. coli O 67一)* \\
\hline P 11c & 2. coli $0 \mathrm{72}$-)* \\
\hline в $\mathbf{8 1 0 a}$ & O 85 (E. coli O 94-)* \\
\hline Leo 429 & O $36(E$. coli O 122)* \\
\hline 2624/36 (S. coli 1 & O 37 (S. djakarta-O 48) \\
\hline BR 184/6 & O 38 (S. kentucky-O 8, 20 \\
\hline LG 1099 & O 39 (S. anatum-O 3, 10) \\
\hline Ci 47007 & O 40 (S. locarno-O 57) \\
\hline Ci 47010 & O 41 (S. tranoroa-O 55) \\
\hline Ci 47012 & O 42 (S. uccle-O 54) \\
\hline
\end{tabular}

\section{Further serologically identical strains}

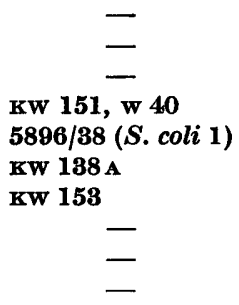

* These cultures have in the meantime been excluded from $E$. coli-type cultures.

The results of serological examinations are summarized in Table 3. In this table the antigenic relationships of all the cultures are expressed and in the case of Citrobacter cultures also their respective serological $O$ groups according to the scheme of West \& Edwards. All the Citrobacter strains were tested with Salmonella O sera 1-60, Shigella sera A I, A II, B, C I, C II, D, and coli sera O 1-144, as well as Citrobacter $\mathrm{O}$ sera 1-32. Some of the strains did not agglutinate in any of them and are not included in Table 3. The results shown in this Table are in complete agreement with the earlier known antigenic relationships of the genera Citrobacter and Salmonella (Edwards \& Ewing, 1962; Kauffmann, 1941) as well as with the original statement of Kauffmann (1941) concerning the so-called Salmonella coli 1-4 cultures.

The antigenic relationship of the further Citrobacter cultures with Salmonella locarno, S. kentucky, S. anatum, S. uccle, S. tranoroa, Shigella flexneri 4 a and Escherichia coli $\mathrm{O} 122$ have, according to literature available to us, not yet been described. One of the Citrobacter strains (Ci 47002) with a Vi antigen is interesting. Its somatic antigen is entirely different from all other known Citrobacter $\mathrm{O}$ antigens including those of groups $\mathrm{O} 5$ and $\mathrm{O} 29$ (Ballerup group), which usually possess 
Vi antigen (Kauffmann, 1954; West \& Edwards, 1954). The antigenic relationship of another Citrobacter culture (47013, provisional $O$ 37), with $S$. flexneri 4 a and the very near relationship of Citrobacter strain Leo 419 (provisional $O$ 36) with test strain $E$. coli $\mathrm{O} 122$ also deserves mention.

In 11 strains of the Hafnia group very close antigenic relationship could be proved with Shigella flexneri 4a as was pointed out by van Oye \& Ghysels (1961). Apart from that, antigenic relationship of two other Hafnia strains with Citrobacter of the provisional $\mathbf{O}$ group 37 was found.

\section{DISCUSSION AND CONCLUSION}

We have tried to show that by using suitable biochemical and serological methods differentiation of Citrobacter as well as Hafnia and Aerobacter cloacae strains within the framework of the family Enterobacteriaceae is feasible. Further, that systematic study of the antigenic relationships of the less-frequently isolated species of enteric bacteria has its theoretical as well as practical importance. In this connexion we met a well-known and often discussed problem, the taxonomic value of the MR and VP tests and $\mathrm{H}_{2} \mathrm{~S}$ production, which are of basic significance and importance in the taxonomy of the family Enterobacteriaceae.

It is well known that the results of MR and VP tests are significantly influenced by many factors; for example, the relative proportion and purity of the reagents, the size of the inoculum and the temperature and duration of the incubation (Kauffmann, 1956; Suassuna, Suassuna \& Ewing, 1961; Hugh, 1965).

In the $\mathrm{H}_{2} \mathrm{~S}$ test there is a considerable difference in the sensitivity depending on the medium used (TSI agar, ferrous chloride gelatin, lead acetate agar, lead acetate test papers). The most sensitive indicator is lead acetate paper, but because of this quality it loses its diagnostic value, and even some Shigella strains will give slight and late positive results when grown on suitable media. Lead acetate agar is less sensitive, but with this it is possible to exclude the weakest $\mathrm{H}_{2} \mathrm{~S}$; for example, some strains of Salmonella typhi, S. choleraesuis, S. gallinarum-pullorum, Citrobacter, Enterobacter and Hafnia. The sensitivity of ferrous chloride gelatin and TSI agar and all their known modifications is practically equal; they show only the production of relatively larger quantities of $\mathrm{H}_{2} \mathrm{~S}$, as is usually produced by the majority of Salmonella, Arizona, Citrobacter, Proteus vulgaris, P. mirabilis cultures and perhaps by the newly described Edwardsiella strains (Ewing, Worther, Escobar \& Lubin 1965). Kauffmann (1954) used ferrous chloride gelatin; Edwards \& Ewing (1962) used TSI agar and stated: ' . . this medium corresponds very closely to the classical descriptions of the various groups of enteric bacteria...' It is essential to know what culture medium was used for $\mathrm{H}_{2} \mathrm{~S}$ detection, and the results obtained by two methods (TSI agar, and lead acetate agar) are shown in Table 2.

In the genus Citrobacter we consider the extension and completion of the existing antigenic scheme of West \& Edwards (1954) to be a logical aim. From our experience we are convinced that this is the only way to reach the correct conclusions on the part played by the different serological types of Citrobacter in the diarrhoeal diseases of man and animals (Sedlák \& Rische, 1961). Our view of the Hafnia group is the same, and we agree with Dr E. van Oye (personal communication) who considers these cultures to be a likely cause of human dysentery. 
The conclusions of our taxonomic study of 36 cultures of less common of Enterobacteriaceae can be summarized as follows:

The cultures described originally by Kauffmann (1941) as Salmonella coli 1-4 are typical Citrobacter cultures. Strains ' $S$. coli 3 and 4' belong to $O$ group 22 of the antigenic scheme of Citrobacter. Also a further four strains of Escherichia coli $(\mathbf{O} 67$, 0 72, 0 94 and 0 122) belong the genus Citrobacter and the test strain w 40 (O 122) is very closely related to the Citrobacter provisional test strain $\mathbf{O} 37$.

An antigenic relationship has been described for the first time between Citrobacter group $\mathrm{O} 12$ and Salmonella locarno, Citrobacter provisional group $\mathrm{O} 38$ and S. kentucky, and Citrobacter provisional group $\mathrm{O} 37$ and $S$. anatum; in two further Citrobacter strains their relationship with $S$. uccle (O 54) and $S$. tranoroa $(\mathbf{O} 55)$ has been newly described.

An antigenic relationship first described by van Oye in 11 Hafnia strains with Shigella flexneri 4a has been confirmed and a new relationship between two Hafnia strains and Citrobacter provisional $\mathbf{O}$ group 37 described.

The authors are indebted to Dr S. T. Cowan and Dr Joan Taylor for their helpful advice concerning the final shape of this manuscript.

\section{REFERENCES}

Bergey's Manual of Determinative Bacteriology (1957), 7th ed. Baltimore: Williams and Wilkins.

Brunner, D. W., Edwards, P. R. \& Hopson, A. S. (1949). J. infect. Dis. 85, 290 (cited by Edwards \& Ewing, 1962).

Edwards, P. R. \& Ewing, W. H. (1955). Identification of Enterobacteriaceae, 1st ed. Minneapolis: Burgess Publ.

Edwards, P. R. \& Ewing, W. H. (1962). Identification of Enterobacteriaceae, 2nd ed. Minneapolis: Burgess Publ.

Edwards, P. R., West, M. G. \& Brunner, D. W. (1948). J. Bact. 55, 711 (cited by Edwards $\&$ Ewing, 1962).

Ewing, W. H., Worther, A. C., Escobar, M. R. \& Lubin, A. H. (1965). Edwardsiella, a new genus of Enterobacteriaceae based on a new species E. tarda. Int. Bull. Bact. Nomenc. Taxon., 15, 33.

Hormaeche, E. \& Edwards, P. R. (1959). Observations on the genus Aerobacter with a description of two species. Int. Bull. bact. Nomenc. Taxon. 8, 111.

HUGH, R. (1965). A comparison of the proposed neotype strain and 258 isolates of Vibrio cholerae Pacini. Int. Bull. bact. Nomec. Taxon. 15, 13.

KAMPELmacher, E. H. (1959). On antigenic relationships between the groups Salmonella, Arizona, Escherichia and Shigella. Antonie van Leeuwenhoek, 25, 289.

Kauffmann, F. (1941). Die Bakteriologie der Salmonella Gruppe. Copenhagen: E. Munksgaard.

Kauffmann, F. (1954). Enterobacteriaceae, 2nd ed. Copenhagen: E. Munksgaard.

Kauffmann, F. (1956). Zentbl. Bakt.ParasitKde, I. Orig. 165, 344 (cited by Sedlák \& Rische, 1961).

Kauffmann, F. (1961). Die Bakteriologie der Salmonella Species. Copenhagen: E. Munksgaard.

Kauffmann, F. (1964). Das Kauffmann-White Schema. In The World Problem of Salomnellosis. Ed. by E. van Oye. Haag: Dr W. Junk.

Kauffmann, F. \& Petersen, A. (1956). The biochemical group and type differentiation of Enterobacteriaceae by organic acids. Acta path. microbiol. scand. 38, 481.

Møller, V. (1954). Diagnostic use of Braun KCN test within the Enterobacteriaceae. Acta path. microbiol. scand. 34, 115. 
van Oye, E. \& Ghysels, G. (1961). Antigenic relationship between Hafnia and Shigella flexneri. J. Bact. 82, 313.

Reports of the Internat. Subcommittee on Enterobacteriaceae (1958). Int. Bull. bact. Nomenc. Taxon. 8, 1.

SEDLAK, J. P \& Rische, H. (1961). Enterobacteriaceae Infektionen. Leipzig: Georg Thieme Verlag.

Suassuna, I., Suassuna, I. R. \& Ewing, W. H. (1961). The methyl-red and VogesProskauer reactions of Enterobacteriaceae. Bull. Conf. St.prov. publ. Hlth Lab. Dir. 19, 67. West, M. G. \& Edwards, P. R. (1954). Publ. Hlth Monogr. 22, (cited by Edwards and Ewing, 1962). 